\title{
Surgical glove perforation during oral and maxillofacial surgical procedures: An experimental study
}

\author{
Perfuração de luva cirúrgica durante procedimentos cirúrgicos bucomaxilofaciais: Um estudo \\ experimental \\ Perforación del guante quirúrgico durante procedimientos quirúrgicos orales y maxilofaciales: Un \\ estudio experimental
}

Received: 04/21/2021 | Reviewed: 04/28/2021 | Accept: 05/06/2021 | Published: 05/19/2021

\author{
Lívia Mirelle Barbosa \\ ORCID: https://orcid.org/0000-0002-8992-2890 \\ Universidade de Pernambuco, Brazil \\ E-mail: dra.liviabarbosa@gmail.com \\ Sylvia Sampaio Peixoto \\ ORCID: https://orcid.org/0000-0002-2147-2627 \\ Universidade Federal de Pernambuco, Brazil \\ E-mail: sampaio_sylvia@outlook.com \\ João Luiz Gomes Carneiro Monteiro \\ ORCID: https://orcid.org/0000-0001-6826-0798 \\ Universidade de Pernambuco, Brazil \\ E-mail: joaoluizgcm2@gmail.com \\ Caroline Dantas Albuquerque Carneiro \\ ORCID: https://orcid.org/0000-0003-1857-2499 \\ Fundação Oswaldo Cruz, Brazil \\ E-mail: carol_dantas@hotmail.com \\ Lívia Maria Lopes de Oliveira \\ ORCID: https://orcid.org/0000-0002-7579-9254 \\ Universidade Federal de Pernambuco, Brazil \\ E-mail: livialopesperiodontia@gmail.com \\ Adriano Costa Ramos \\ ORCID: https://orcid.org/0000-0001-5896-4513 \\ Universidade Federal de Pernambuco, Brazil \\ E-mail: adrianocramos1@gmail.com \\ Gabriela Madeira Araújo \\ ORCID: https://orcid.org/0000-0003-3999-9547 \\ Universidade Federal de Pernambuco, Brazil \\ E-mail: dragabrielamadeiraa@gmail.com \\ Ricardo Viana Bessa-Nogueira \\ ORCID: https://orcid.org/0000-0002-9776-6752 \\ Universidade federal de Alagoas, Brazil \\ E-mail: Ricardo-bessa@ foufal.ufal.br \\ José Rodrigues Laureano Filho \\ ORCID: https://orcid.org/0000-0002-9645-2057 \\ Universidade de Pernambuco, Brazil \\ E-mail: laureano.filho@upe.br \\ Belmiro Cavalcanti do Egito Vasconcelos \\ ORCID: https://orcid.org/0000-0002-6515-1489 \\ Universidade de Pernambuco, Brazil \\ E-mail: Belmiro.vasconcelos@gmail.com
}

\begin{abstract}
Propouse: surgical teams sometimes neglect surgical glove perforation. The aim of this study was to determine the prevalence of sterile glove perforation in maxillofacial surgical procedures. Methods: Two studies were performed. The first one evaluated 200 pairs of surgical gloves (50 in each group) used by first, second, and third-year residents $(\mathrm{R} 1, \mathrm{R} 2, \mathrm{R} 3)$. In the second study, 150 pairs of surgical gloves were evaluated: 100 pairs were used by a third-year resident, including 50 pairs in oral surgery procedures and 50 pairs in trauma surgeries, and 50 pairs of unused gloves were tested as control. The gloves were examined for perforations by filling them with water and testing for leaks. Results: In the first study, 29 pairs (19.3\%) were perforated. Of the 50 pairs of control gloves, 7 pairs (14\%) showed perforations on either side. The thumb and index finger and the right-hand (dominant hand) gloves, were the most frequently perforated sites. In the second study, $6 \%$ of the gloves in the control group, $6 \%$ of the gloves used in oral
\end{abstract}


surgeries, and $10 \%$ of the gloves used in trauma surgeries showed perforations. The index finger and thumb were the most affected sites. Conclusion: The perforation rate was higher for the dominant right hand. In both studies, the frequency of perforation of unused gloves was significant, indicating the need for better quality control of the gloves evaluated in this study.

Keywords: Oral surgical procedures; Oral and maxillofacial surgeons; Risk factors; Gloves surgical.

\section{Resumo}

Proposta: as equipes cirúrgicas às vezes negligenciam a perfuração das luvas cirúrgicas. O objetivo deste estudo foi determinar a prevalência de perfuração de luva estéril em procedimentos cirúrgicos maxilofaciais. Métodos: Dois estudos foram realizados. O primeiro avaliou 200 pares de luvas cirúrgicas (50 em cada grupo) utilizadas por residentes do primeiro, segundo e terceiro anos (R1, R2, R3). No segundo estudo, foram avaliados 150 pares de luvas cirúrgicas: 100 pares foram usados por um residente do terceiro ano, incluindo 50 pares em procedimentos de cirurgia oral e 50 pares em cirurgias de trauma, e 50 pares de luvas não utilizadas foram testados como controle. As luvas foram examinadas quanto a perfurações, enchendo-as com água e testando quanto a vazamentos. Resultados: No primeiro estudo, 29 pares (19,3\%) foram perfurados. Dos 50 pares de luvas controle, 7 pares (14\%) apresentaram perfurações em ambos os lados. O polegar e o dedo indicador e as luvas da mão direita (mão dominante) foram os locais mais perfurados. No segundo estudo, 6\% das luvas do grupo controle, $6 \%$ das luvas utilizadas em cirurgias orais e $10 \%$ das luvas utilizadas em cirurgias de trauma apresentaram perfurações. O dedo indicador e o polegar foram os locais mais afetados. Conclusão: A taxa de perfuração foi maior para a mão direita dominante. Em ambos os estudos, a frequência de perfuração de as luvas não utilizadas foi significativa, indicando a necessidade de melhor controle de qualidade das luvas avaliadas neste estudo.

Palavras-chave: Procedimentos cirúrgicos bucais; Cirurgiões bucomaxilofaciais; Fatores de risco; Luvas cirúrgicas.

\section{Resumen}

Propuesta: los equipos quirúrgicos a veces descuidan perforar los guantes quirúrgicos. El objetivo de este estudio fue determinar la prevalencia de perforación del guante estéril en procedimientos quirúrgicos maxilofaciales. Métodos: Se realizaron dos estudios. El primero evaluó 200 pares de guantes quirúrgicos (50 en cada grupo) utilizados por residentes de primer, segundo y tercer año (R1, R2, R3). En el segundo estudio, se evaluaron 150 pares de guantes quirúrgicos: un residente de tercer año utilizó 100 pares, incluidos 50 pares en procedimientos de cirugía oral y 50 pares en cirugías de trauma, y se probaron 50 pares de guantes sin usar como controles. Se examinaron los guantes en busca de perforaciones, se llenaron de agua y se analizaron para detectar fugas. Resultados: En el primer estudio se perforaron 29 pares (19,3\%). De los 50 pares de guantes de control, 7 pares (14\%) tenían perforaciones en ambos lados. El pulgar, el índice y los guantes de la mano derecha (mano dominante) fueron los sitios más perforados. En el segundo estudio, el $6 \%$ de los guantes en el grupo de control, el $6 \%$ de los guantes usados en cirugías bucales y el $10 \%$ de los guantes usados en cirugías traumatológicas presentaban perforaciones. El dedo índice y el pulgar fueron los sitios más afectados. Conclusión: La tasa de perforación fue mayor para la mano derecha dominante. En ambos estudios, la frecuencia de perforación de los guantes sin usar fue significativa, lo que indica la necesidad de un mejor control de calidad de los guantes evaluados en este estudio.

Palabras clave: Procedimientos quirúrgicos orales; Cirujanos oromaxilofaciales; Factores de riesgo; Guantes quirúrgicos.

\section{Introduction}

Dentists are routinely exposed to patients' organic fluids, such as blood and saliva, and to the microorganisms present in these fluids. Depending on the condition of the patient, dentists may be exposed to agents that cause contagious diseases, such as hepatitis B and C and acquired immunodeficiency syndrome (AIDS) and more recently by SARS-COV-2, for having a fast and continuous transmission reason for which was decreed by the World Health Organization (WHO) to be a pandemic on March 11, 2020 (WHO, 2020; Makama, Okeme, Makama, \& Ameh, 2016). The main route of spread of these viruses occurs through contact with blood and through respiratory droplets produced when someone infected (Brasil, 2020). In this context, it is essential to adopt safe means during contact with the patient to prevent viral spread. The use of epi's as a protective measure is critical (Rodrigues, Pereira, \& Ferreira Junior, 2013). Among these measures, physical barriers, such as the use of gloves, must remain intact to be effective as protective barriers, guaranteeing their impermeability to possible pathogens for health professionals and the general population (Brasil, 2020; Rodrigues, Pereira, \& Ferreira Junior, 2013). In surgical practices, perforation of the surgical glove is a relatively common event. For this reason, the importance of pre-operative hand brushing with antiseptic to maintain its action during the operation (Murta, Silva, \& Ferreira, 2000). In this perspective, the literature 
shows that the proper use of gloves, associated with the practice of hand hygiene, is a determining factor for the protection of professionals during health care, whether at the hospital level and / or in primary care. Notwithstanding this, according to NR 32 , the use of gloves does not replace the hand hygiene process, which must occur, at least, before and after the use of gloves (Brasil, 2020). Therefore, procedures performed by maxillofacial surgeons present a high biological risk, with a higher risk of contracting these diseases than dentists of other specialties, mainly because of the use of cutting instruments in an often restricted operating field. Perforation of the surgical glove is an important problem that is sometimes overlooked by surgical teams and can expose both patients and professionals to complications (Tlili et al., 2018), as it can increase the risk of crosscontamination (Rodrigues, Pereira, \& Ferreira Junior, 2013; Kuroyanagi et al. 2012). However, it is not clear how often these perforations occur in oral and maxillofacial surgery procedures.

The aim of this study was to determine the frequency of glove perforation related to minor oral surgery and maxillofacial trauma procedures performed by oral and maxillofacial surgery residents.

\section{Methods}

Two studies were performed: in the first, the frequency of surgical glove perforation during third molar extraction procedures performed by maxillofacial surgery residents was determined. In the second study, the surgical gloves used by the first author of this article during her third and final year of training in oral and maxillofacial surgery were analyzed. The methodology for each study is described below. The study was approved by the Ethics Committee of Universidade de Pernambuco (Protocol 0108.0.097.000-10).

\section{Study 1}

Two hundred pairs of sterile surgical latex gloves (New Hand, Lemgruber®, Rio de Janeiro, Brazil) were analyzed. The gloves were used by residents during oral surgeries in the Department of Clinical Research in Oral and Maxillofacial (Universidade de Pernambuco, Recife, Brazil). Fifty pairs were used by first-year residents (R1), 50 by second-year residents (R2), 50 by third-year residents (R3), and 50 pairs of unused gloves constituted the control group. All residents of this study were right-handed.

The method used for the evaluation of glove puncture has been previously validated and is an easy, inexpensive and reproducible tool that permits to test a large number of gloves. Each glove was filled with $500 \mathrm{ml}$ of water and held at its cuff against a dark and opaque background. A gentle pressure was then applied, and the following areas of the glove were visually inspected by a single investigator for 20 seconds: the palm, the back, and the fingers. All inspection data were computed. We also investigated the occurrence of percutaneous injuries among participants during the procedures.

Statistical analysis was performed with the SPSS ${ }^{\circledR}$ for Windows® software (version 14; SPSS, Inc., Washington, USA). Statistical significance was calculated using the chi-square test, Pearson test, and odds ratio, adopting a level of significance of $5 \%$.

\section{Study 2}

The sample was composed of gloves used by a third-year oral and maxillofacial surgery resident (LMB) in the operating rooms of Hospital da Restauração and Hospital da Face, both located in Recife (Pernambuco, Brazil). A total of 150 pairs of surgical sterile gloves (New Hand, Lemgruber®, Rio de Janeiro, Brazil) were divided as follows: 50 pairs of gloves used in minor oral surgical procedures (group I), 50 pairs of gloves used in facial trauma surgeries (group II), and 50 pairs of unused gloves (control group) to identify possible manufacturing defects, totaling 100 gloves per group. Minor oral surgeries included procedures such as tooth extraction, biopsy or excision of soft/hard tissue lesions, and lingual or labial frenectomy. 
Facial trauma surgeries were performed for the reduction and fixation of fractures of the facial bones. The procedures used for the verification of perforations were the same as those described for study 1 .

Data were analyzed with the SPSS ${ }^{\circledR}$ for Windows ${ }^{\circledR}$ software (version 14; SPSS, Inc., Washington, USA). Statistical significance was calculated using the Pearson test or ANOVA, with the level of significance set at 5\%.

\section{Results}

\section{Study 1}

Twenty-nine (19.3\%) of the 150 pairs of gloves used by residents were perforated. Table 1 summarizes the distribution of pairs of perforated gloves according to each resident group. None of the perforations was observed during the procedures. Of the 50 pairs of control gloves, 7 pairs (14\%) showed perforations on either side, 5 left-hand and 2 right-hand gloves. There were 12 perforations among these 7 pairs of gloves. The number of perforated pairs ranged from 6 to 12 among resident groups. There was no statistically significant difference in the number of perforations between groups $(\mathrm{X} 2=3.523, \mathrm{p}$ $=0.318)$. Considering the gloves used by residents of the three groups, the left hand had $2.3 \%$ less perforations than the right hand (dominant hand).

According to the data in Table 2, the thumb and index fingers were the most affected sites (27.27\% each) in all three groups of residents, followed by the ring finger $(15.15 \%)$.

\section{Study 2}

The frequency of perforated pairs per group $(\mathrm{n}=50)$ was $6 \%$ among gloves used in oral surgeries, $6 \%$ among unused gloves (control group), and 10\% among gloves used in trauma surgeries. No significant difference ( $p>0.05$ and $\mathrm{CI}$ including 1.00) in the percentage of perforated gloves was observed between groups (Table 3 ).

According to Table 3 , the percentage of perforations was $8 \%$ among pairs used during the procedures and $6 \%$ among unused gloves (control group), with no significant difference between these groups ( $p>0.05$ ). Regarding the perception of perforations during the procedures, among the 8 pairs with some perforation, the perforation was noticed in only one pair, which belonged to the group of gloves used in trauma surgeries.

According to Table 4, the most frequently perforated fingers were the thumb in minor oral surgical procedures and the index finger in trauma surgeries. Furthermore, the right-hand glove was most frequently affected by perforations. It is important to emphasize that the right hand corresponds to the dominant hand of the surgeon of the present study. Percutaneous injuries did not occur in either study.

\section{Discussion}

The use of gloves is an essential practice for healthcare professionals, as it protects the patient and professionals against biological threats such as viruses, bacteria and other pathogens by creating a mechanical barrier. Among healthcare professionals, surgeons are at higher risk of contact with the patient's blood and body fluids. Therefore, the perforation of gloves may expose the surgical team to a greater risk of infection (Burke, 1990; Xavier, 2006). Among dental specialties, the probability of cross-contamination is higher in oral and maxillofacial facial surgery because of the larger number of procedures using perforating-cutting materials (Rodrigues, Pereira, \& Ferreira Junior, 2013).

Most studies evaluating glove perforation use the water inflation technique and compare the results of gloves used in oral and maxillofacial surgeries with unused gloves (control group). Evaluation of unused gloves (control group) showed a frequency of glove perforation of $14 \%$ in study 1 and of $3 \%$ in study 2 , demonstrating the need for better quality control of the 
brand studied since some studies found no perforations in the control group (Makama, Okeme, Makama, \& Ameh, 2016; Rodrigues, Pereira, \& Ferreira Junior, 2013; Xavier, 2009). This result shows that surgical teams must investigate the quality of the brand used during their procedures.

Analyzing the integrity of the gloves used in oral surgeries, a frequency of $19.3 \%$ of perforated gloves was found in study 1 and of $3 \%$ in study 2 . This divergence can be explained by differences in the methodology of the studies. While the first study analyzed gloves used by residents with different levels of training, the second study analyzed only gloves used by a last-year resident who has more experience in surgical practice. Another methodological difference is that the surgical procedures performed in study 1 included only third molar extraction surgeries, whereas in the second study, simpler and faster oral procedures such as frenectomies and biopsies were included.

There was no significant difference in the frequency of perforated gloves between the surgical procedures and the control group in either study. This finding suggests that the perforations found in the gloves used in the surgical procedures cannot necessarily be attributed to the surgical procedure itself, but to the quality of the material.

Similar studies evaluating glove perforation among oral and maxillofacial surgery residents found ranged from 1,5 to $5 \%$. The frequency of glove perforation is influenced by the type and duration of the procedure, as well as by the time of surgeon training (Rodrigues, Pereira, \& Ferreira Junior, 2013). In the study by Kuroyagani et al. 2012, the highest perforation rate was found in the group of orthognathic surgeries; however, the authors did not evaluate any trauma category. In study 2 of the present paper, there was a higher frequency of perforation in pairs of gloves used in maxillofacial trauma surgeries, although the result was not statistically significant. A higher risk of glove perforation is observed in maxillofacial trauma surgeries, which may be associated with intermaxillary interoperative fixation, use of drills and screws, and contact with sharp bone edges of fractured segments. These factors can increase the risk of percutaneous injuries and consequently the risk of contamination by the operator (Avery, 1999). Brandtner, Borumandi, Krenkel e Gaggl (2015) suggested the use of blunt-tipped steel wires produced by welding wire ends, which are less likely to cross the gloves, as an alternative to conventional steel wires (Avery, 1999).

Some studies have evaluated the frequency of glove perforation in other surgical specialties, with rates of $13 \%$ in gynecological cancer surgery (Brandtner, Borumandi, Krenkel, \& Gaggl, 2015) 6,25\% in arthroplasty surgery (Manjunath, 2008) and 54,3\% in abdominal surgeries (Kumar, 2016). In the present investigation, a low degree of perception of glove perforations was observed in the two studies. This failure to detect glove perforation during the surgical procedure has also been reported by other authors (Makama, Okeme, Makama, \& Ameh, 2016; Rodrigues, 2013; Burke, 1996; Xavier, 2006).

In surgical procedures, glove replacement at regular intervals ( 2 hours) has been recommended as an effective way to decrease the prevalence of glove perforation. Double gloving has also been suggested to be more efficient than single gloving. The outer glove protects the inner glove without apparently affecting surgical performance (Makama, 2016; Rodrigues, Pereira, \& Ferreira Junior, 2013; Manjunath, 2008; Kumas, 2016; Sayin, 2016).

\section{Conclusion}

The frequency of perforation of unused gloves (control group) was significant, indicating that the surgeon and his team should investigate the quality of the brands used. The perception of glove perforation during the surgical procedure was deficient. Thus, it is recommended to carry out further research to consolidate this topic.

\section{Acknowledgements}

I have made substantive intellectual contributions to the content of this manuscript in the following areas: 


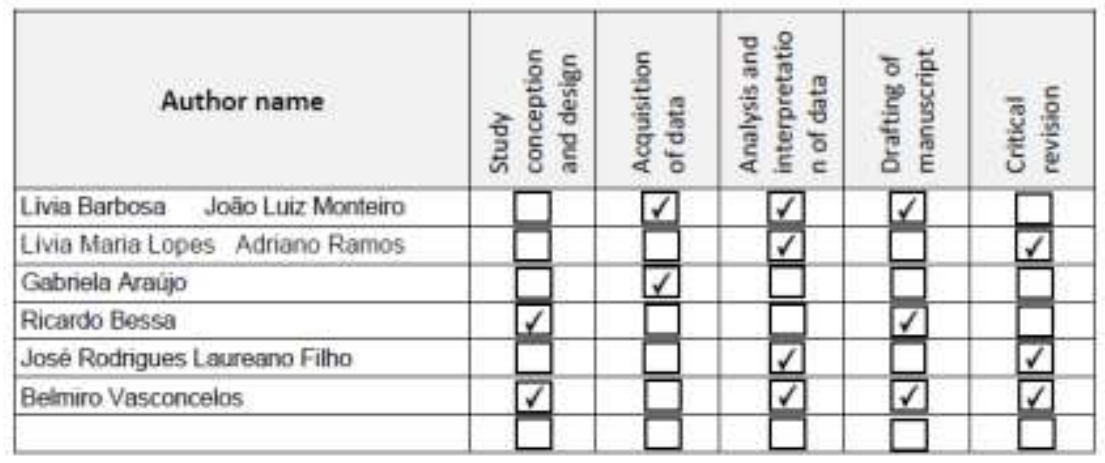

\section{References}

Anderson, R. M., Heesterbeek, H., Klinkenberg, D., \& Hollingsworth, T. D. (2020). How will country-based mitigation measures influence the course of the COVID-19 epidemic? The Lancet, 395(10228), 931-934.

Avery, C. M. E., Taylor, J., \& Johnson, P. A. (1999). Double gloving and a system for identifying glove perforations in maxillofacial trauma surgery. British Journal of Oral and Maxillofacial Surgery, 37(4), 316-319.

Bessa, M. M., Lima, L. S., Silva, M. D. M., \& Freitas, R. J. M. (2020). Gloves as a preventive measure for Covid-19: who should use it? Research, Society and Development, 9(8): 1-10, e746974846.

Brandtner, C., Borumandi, F., Krenkel, C., \& Gaggl, A. (2015). Blunt wires in oral and maxillofacial surgery. British Journal of Oral and Maxillofacial Surgery, 53(3), 301-302.

Brasil. Agência Nacional de Vigilância Sanitária. (2010). Primeiro desafio mundial para a segurança do paciente. Uso de luvas (técnico). Folha informativa 6: p2. http://www.anvisa.gov.br/servicosaude/controle/higienizacao_oms/folha\%20informativa\%20 6.pdf.

Brasil. Agência Nacional de Vigilância Sanitária. (2011). Resolução no 55, de 4 de novembro de 2011. Estabelece os requisitos mínimos de identidade e qualidade para as luvas cirúrgicas e luvas para procedimentos não cirúrgicos de borracha natural, de borracha sintética, de mistura de borrachas natural e sintética e de policloreto de vinila, sob regime de vigilância sanitária. http://www.lex.com.br/doc_22237184 _RESOLUCAO_N_55_DE_4_DE_NOVEMBRO_DE_2011.aspx.

Brasil. Ministério da Saúde. (2020). Protocolo de Tratamento do Novo Coronavírus (2019-nCoV). Tiragem: $1^{\text {a }}$ edição - 2020 - publicação eletrônica. https://portalarquivos2.saude.gov.br/images/pdf/2020/fevereiro/05/Protocolo-de-manejo-clinico-para-o-novo-coronavirus-2019-ncov.pdf.

Burke, F. J., \& Wilson, N. H. (1990). The incidence of undiagnosed punctures in non-sterile gloves. British dental journal, 168(2), 67-71.

Burke, F. J. T., Baggett, F. J., \& Lomax, A. M. (1996). Assessment of the risk of glove puncture during oral surgery procedures. Oral Surgery, Oral Medicine, Oral Pathology, Oral Radiology, and Endodontology, 82(1), 18-21.

Fareedi, A. L. I., Chandra, P., Patil, K., \& Tahasildar, S. (2016). Double gloving in dentistry: importance and recommendations: a review. International Arab Journal of Dentistry (IAJD), 7(1), 37-40.

Gaujac, C., Ceccheti, M. M., Yonezaki, F., Garcia Jr, I. R., \& Peres, M. P. S. (2007). Comparative analysis of 2 techniques of double-gloving protection during arch bar placement for intermaxillary fixation. Journal of Oral and Maxillofacial Surgery, 65(10), 1922-1925.

Hardison, S. A., Pyon, G., Le, A., Wan, W., \& Coelho, D. H. (2017). The effects of double gloving on microsurgical skills. Otolaryngology-Head and Neck Surgery, 157(3), 419-423.

Jid, L. Q., Ping, M. W., Chung, W. Y., \& Leung, W. Y. (2017). Visible glove perforation in total knee arthroplasty: Risk and consequences. Journal of Orthopaedic Surgery, 25(1), 2309499017695610.

Kumar, D., Shantanu, K., Kumar, M., Kumar, A., \& Sharma, V. (2016). A Cross-sectional Analysis of Glove Perforation in Primary and Revision Total Hip Arthroplasty. Malaysian orthopaedic journal, 10(3), 31 .

Kuroyanagi, N., Nagao, T., Sakuma, H., Miyachi, H., Ochiai, S., Kimura, Y., Fukano, H., \& Shimozato, K. (2012). Risk of surgical glove perforation in oral and maxillofacial surgery. International journal of oral and maxillofacial surgery, 41(8), 1014-1019.

Luize, P. B. (2018). Avaliação da Integridade de luvas cirúrgicas em um hospital oncológico no interior paulista. Tese de doutorado, Universidade de São Paulo, Ribeirão Preto, SP, Brasil.

Lutsky, K. F., Jones, C., Abboudi, J., Kirkpatrick, W., Liss, F., Leinberry, C., Ilyas, A., Martin, D., \& Beredjiklian, P. K. (2017). Incidence of glove perforation during hand surgical procedures. The Journal of hand surgery, 42(10), 840-e1.

Makama, J. G., Okeme, I. M., Makama, E. J., \& Ameh, E. A. (2016). Glove perforation rate in surgery: a randomized, controlled study to evaluate the efficacy of double gloving. Surgical infections, 17(4), 436-442.

Manjunath, A. P., Shepherd, J. H., Barton, D. P. J., Bridges, J. E., \& Ind, T. E. J. (2008). Glove perforations during open surgery for gynaecological malignancies. BJOG: An International Journal of Obstetrics \& Gynaecology, 115(8), 1015-1019. 
Research, Society and Development, v. 10, n. 6, e2610615290, 2021

(CC BY 4.0) | ISSN 2525-3409 | DOI: http://dx.doi.org/10.33448/rsd-v10i6.15290

Murta, E. F. C., Silva, C. S. D., \& Ferreira, N. A. F. D. (2000). Perfuração de luvas durante cirurgias ginecológicas. Revista Brasileira de Ginecologia e Obstetrícia, 22(4), 225-228.

Organização Mundial da Saúde (OMS). (2014). Salve Vidas: Higienize suas Mãos. Higiene das Mãos na Assistência à Saúde Extra-hospitalar e Domiciliar e nas Instituições de Longa Permanência - Um Guia para a Implementação da Estratégia Multimodal da OMS para a Melhoria da Higiene das Mãos e da Abordagem "Meus 5 Momentos para a Higiene das Mãos"; tradução de OPAS. Organização Pan-Americana da Saúde; Agência Nacional de Vigilância Sanitária; $73 \mathrm{p}$

Pérez-Serrano, M. E., Diniz-Freitas, M., Fernández-Feijoo, J., \& Limeres-Posse, J. (2017). Glove perforations during routine dental hygienist procedures in a primary care setting. Atencion primaria, 50(2), 130-131.

Rodrigues, V. P., Pereira, A. L. A., \& Ferreira Júnior, A. J. D. (2013). Incidência de perfurações em luvas de látex estéreis utilizadas por estudantes nas clínicas de periodontia e cirurgia bucal. Odontologia Clínico-Científica (Online), 12(4), 255-259.

Sayın, S., Yllmaz, E., \& Baydur, H. (2019). Rate of glove perforation in open abdominal surgery and the associated risk factors. Surgical infections, 20(4), 286-291.

Tlili, M. A., Belgacem, A., Sridi, H., Akouri, M., Aouicha, W., Soussi, S., Dabbebi, F., \& Dhiab, M. B. (2018). Evaluation of surgical glove integrity and factors associated with glove defect. American journal of infection control, 46(1), 30-33.

Xavier, R. L. F., Vasconcelos, B. C. E., Silva, L. C. F., \& Porto, G. G. (2006). Glove perforation during oral surgical procedures. Medicina Oral, Patología Oral y Cirugía Bucal (Internet), 11(5), 433-436. 